\title{
Penyuluhan Pemanfaatan Sampah/Limbah Plastik Menjadi Produk Kreatif Di Kampung Gendingan Surakarta
}

\author{
Tria Rosana Dewi ${ }^{1)}$, Irma Wardani ${ }^{2)}$, Libria Widiastuti ${ }^{3)}$, Rehino Yanu Seto ${ }^{4)}$ \\ Universitas Islam Batik Surakarta \\ email : triardewi@yahoo.co.id
}

\begin{abstract}
Abstrak
Sampah akan terus diproduksi dan tidak akan pernah berhenti selama manusia tetap ada. Dapat dibayangkan bahwa jumlah sampah yang dihasilkan oleh penghuni bumi ini akan semakin meningkat. Sampah sendiri merupakan salah satu bentuk konsekuensi dari adanya aktivitas manusia dan volumenya berbanding lurus dengan jumlah penduduk. Apabila tidak ditangani secara efektif dan efisien, eksistensi sampah di alam tentu akan berbalik menghancurkan kehidupan sekitarnya.

Sumber sampah terbanyak adalah yang berasal dari pemukiman, komposisinya berupa $75 \%$ terdiri dari sampah organik dan sisanya adalah sampah anorganik. Sampah organik telah banyak dimanfaatkan sebagai bahan pembuatan kompos, briket serta biogas, tetapi sampah anorganik masih sangat minim pengelolaannya. Sampah anorganik sangat sulit didegradasi bahkan tidak dapat didegradasi sama sekali oleh alam. Sampah anorganik yang paling banyak dijumpai di masyarakat adalah sampah plastik. Terdapat banyak potensi untuk memanfaatkan sampah plastik menjadi produk dan jasa kreatif dalam rangka mengelola sampah plastik dengan baik, sehingga plastik benar-benar mendukung kehidupan kita. Tidak hanya ketika kita gunakan namun juga setelah kita gunakan. Salah satu upaya untuk mengurangi dampak buruk sampah plastik bagi lingkungan adalah dengan melaksanakan prinsip 3R dalam kehidupan sehari-hari, yaitu pengurangan pemakaian (reduce) pemakaian ulang (reuse), dan pendaur ulang (recycle). Berdasarkan permasalahan tersebut tim pengabdi mengadakan kegiatan pengabdian masyarakat dengan mengusung tema penyuluhan pemanfaatan sampah atau limbah plastik menjadi produk kreatif di kampung Gendingan RT02/16 Jebres, Surakarta.
\end{abstract}

Kata kunci : Sampah, Plastik, Produk kreatif

\section{PENDAHULUAN}

Pola Pengelolaan Sampah sampai saat ini masih menganut paradigma lama dimana sampah masih dianggap sebagai sesuatu yang tak berguna, tak bernilai ekonomis dan sangat menjijikkan. Masyarakat sebagai sumber sampah tak pernah menyadari bahwa tanggung jawab pengelolaan sampah yang dihasilkan menjaditanggung jawab dirinya sendiri. Apabila sampah - sampah yang luar biasa ini mulai menjadi masalah bagi manusia, barulah manusia menyadari ketidak perduliannya selama ini terhadap sampah dan mulai menimbulkan kepanikan dan menghantui di mana-mana tanpa tahu apa yang harus dilakukan untuk mengatasinya. Sampah merupakan konsekuensi dari adanya aktifitas manusia, karena setiap aktifitas manusia pasti menghasilkan buangan atau sampah. Jumlah atau volume sampah sebanding dengan tingkat konsumsi kita terhadap barang material yang kita gunakan sehari-hari. Sehari setiap warga kota menghasilkan rata-rata gram sampah, dengan komposisi, sampah organik dan sampah anorganik (Pujotomo, 2016)

Plastik merupakan material yang baru, secara luas dikembangkan dan digunakan sejak abad ke-20, tepatnya pada tahun 1975 diperkenalkan oleh Montgomery Ward, Sears, J.C. Penny, Jodan Marsh dan toko-toko retail besar lainnya (Marpaung, 2009). Plastik berkembang secara luar biasa penggunaannya dari hanya beberapa ratus ton pada tahun 1930-an, menjadi 150 juta ton/tahun pada tahun 1990-an dan 220 juta ton/tahun pada tahun 2005. Saat ini hampir tidak ada supermarket, took atau warung di Indonesia yang tidak menyediakan kantung plastik (Putra HP, 2010).

Jika ada yang bertanya, material apakah yang membawa manfaat bagi kehidupan sekaligus membahayakan pada saat yang sama, selain api dan air, plastik adalah jawabannya. Plastik telah menjadi sabahat manusia selama hampir satu abad, ia terus diproduksi dan dimanfaatkan sampai saat ini. Sebagai material yang sulit diurai secara alami, idealnya tidak boleh ada plastik yang menumpuk di Tempat Pembuangan Akhir (TPA). Ketika produk dari plastik telah habis masa pakainya, ia dapat didaur ulang dan dimanfaatkan kembali.

Sejauh ini keterlibatan masyarakat dalam mengurangi pemakaian dan mendaur ulang plastik masih sangat minim. Biasanya plastik dibakar untuk memusnahkannya dari pandangan. Padahal, jika 
pembakaran plastik tidak sempurna (di bawah 8000C) dapat membentuk dioksin, yaitu senyawa yang dapat memicu kanker, hepatitis, pembengkakan hati dan gangguan system saraf (Sirait, 2009).

Sampah anorganik yang paling banyak dijumpai di masyarakat adalah sampah plastik. Terdapat banyak potensi untuk memanfaatkan sampah plastik menjadi produk kreatif dalam rangka mengelola sampah plastik dengan baik, sehingga plastik benar-benar mendukung kehidupan kita. Berdasarkan permasalahan tersebut tim pengabdi mengadakan kegiatan pengabdian masyarakat dengan mengusung tema penyuluhan pemanfaatan sampah atau limbah plastik menjadi produk kreatif di kampung Gendingan RT02/16 Jebres, Surakarta.

\section{METODE PENGABDIAN}

\section{a. Pelaksanaan Kegiatan}

1. Perencanaan

Agar program ini berjalan secara maksimal, maka diperlukan perencanaan secara tepat, diantaranya:

a) Menyusun proposal kegiatan pelatihan membuat produk dari sampah/limbah plastik

b) Melakukan survei lapangan dan memastikan obyek masyarakat bersedia menjadi sasaran program

c) Mengamati pentingnya mengadakan program karena latar belakang masyarakat yang memiliki letak stategis dan potensi wilayah

d) Menyusun waktu pelaksanaan kegiatan

e) Meminta izin kepada pihak yang berwenang yang telah bersedia menyediakan sarana kegiatan

f) Mempersiapkan alat dan bahan dalam memberikan pelatihan

2. Pelaksanaan

a) Melakukan sosialisasi pentingnya menjaga lingkungan dan memanfaatkan sampah/limbah plastik sebagai solusi mengatasi pencemaran lingkungan.

b) Menyiapkan alat dan bahan yang digunakan dalam pembuatan produk berbahan baku limbah plastik yang berbasis nilai fungsional.

c) Memberikan penyuluhan kepada masyarakat mengenai cara pembuatan produk-produk kreatif dari sampah/limbah plastik.

d) Melakukan demonstrasi pembuatan produk dari sampah/limbah plastik

e) Mempraktikkan pembuatan produk dari sampah/limbah plastik yang berbasis nilai fungsional.

f) Mengevaluasi hasil pembuatan produk dari sampah/limbah plastik.

\section{b. Target dan luaran pengabdian}

Kontribusi dari kegiatan ini adalah sebagai bentuk pengabdian kepada masyarakat yang memiliki banyak potensi untuk mengembangkan kearifan lokal di daerah tersebut. Luaran yang diharapkan dari program ini adalah sebagai berikut:

1. Sebagai wahana bermanfaat yang dapat memberi pengetahuan kepada masyarakat, bahwa ternyata sampah plastik dapat dimanfaatkan sebagai peluang usaha.

2. Masyarakat dapat menciptakan kreasi produk dengan bahan baku sampah plastik

3. Dengan munculnya pemahaman masyarakat tentang potensi ekonomi dari pemanfaatan sampah plastik

\section{HASIL DAN PEMBAHASAN}

Rincian kegiatan pengabdian kepada masyarakat yang dilakukan di Kampung Gendingan RT02/16 Jebres, Surakarta sebagai berikut :

a. Kegiatan Pengabdian

Kegiatan pengabdian penyuluhan pemanfaatan sampah atau limbah plastik menjadi produk kreatif ini dilaksanakan di Gendingan RT02/16 Jebres, Surakarta dengan dihadiri oleh ibu-ibu warga kampung sekitar. Mereka sangat senang dan mengapresiasi kegiatan ini. Sesuai dengan permasalahan yang dihadapi oleh warga masyarakat dalam kaitannya dengan upaya pengembangan wawasan pengetahuan dan keterampilan pengolahan limbah plastik menjadi 
produk kreatif, maka program pengabdian masyarakat ini dilakukan dalam bentuk transfer iptek yang dilakukan berupa sosialisasi, pelatihan, dan pendampingan. Narasumber pada pengabdian ini selain tim pengabdi dari Universitas Islam Batik juga dibantu oleh ibu Rien Saptanti yang merupakan anggota dharma wanita UNS. Pada kegiatan tersebut narasumber akan memberikan penyuluhan dan pelatihan pembuatan produk seperti topi dan tas yang akan dibuat dari sampah atau limbah plastik.

b. Evaluasi Kegiatan

Tujuan dari kegiatan penyuluhan ini adalah mengedukasi sasaran dengan perubahan pengetahuan, sikap, dan ketrampilan terhadap pelatihan yang disampaikan oleh penyaji. Kegiatan ini meliputi penyuluhan akan bahaya sampah anorganik bagi kehidupan yang salah satunya adalah plastik, pelatihan dan pendampingan dalam membuat produk dari limbah plastik seperti topi dan tas.

Berdasarkan hasil evaluasi tidak lanjut, beberapa manfaat praktis yang diperoleh oleh tim pengabdi dari kegiatan tersebut, antara lain : Pertama, partisipan mendapatkan informasi yang jelas dan utuh mengenai hakekat pemberdayaan masyarakat dari segi pengetahuan dan keterampilan untuk penciptaan lapangan pekerjaan baru yang sifatnya inovatif dari pengembangan industri rumah tanggga. Kedua, partisipan yang menjadi peserta pelatihan memperoleh gambaran yang jelas mengenai langkah pengembangan iklim usaha dengan memanfaatkan limbah plastik. Ketiga, peserta pelatihan juga mendapatkan gambaran yang jelas tentang manfaat limbah jika dikelola dengan baik.

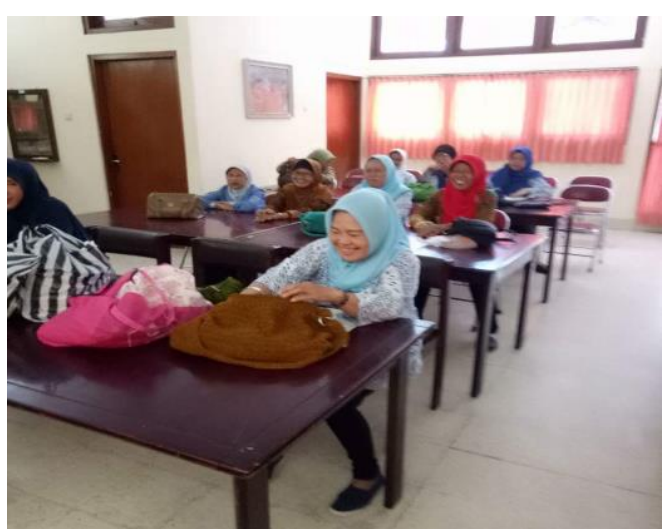

Gambar 1. menggunakan limbah pastik

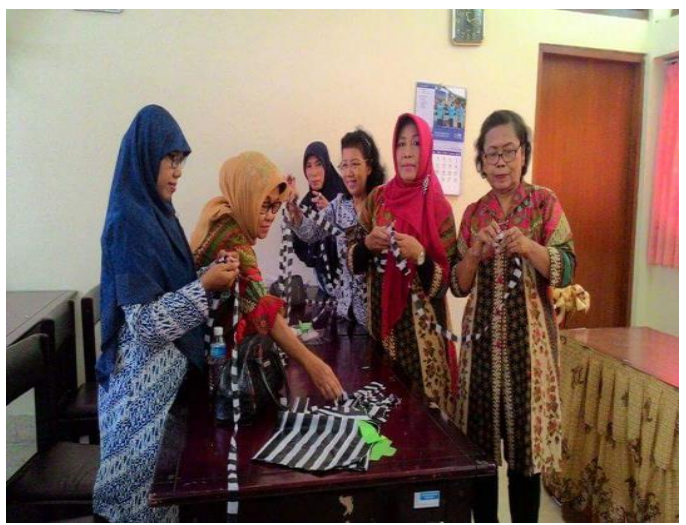

Gambar 2.

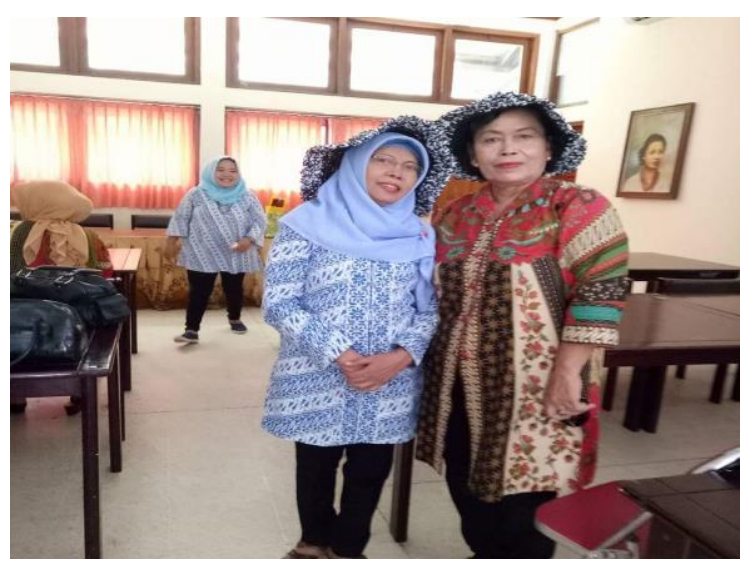

Gambar 3.

Hasil kerajinan topi dari plastik 


\section{SIMPULAN}

Kesimpulan yang dapat diperoleh dari pelaksanaan program pengabdian kepada masyarakat "Penyuluhan Pengolahan Sampah atau Limbah Plastik Menjadi Produk Kreatif" adalah: (1) Tingkat partisipasi yang tinggi dari mitra program pengabdian kepada masyarakat memberikan dampak positif bagi pelaksanaan program, terlihat dari pelatihan dan pendampingan dalam pembuatan produk, (2) Pelaksanaan program mampu menghasilkan produk-produk yang memiliki nilai jual sehingga mampu meningkatkan perekonomian masyarakat setempat.

\section{DAFTAR PUSTAKA}

Marpaung, G.S., dan Widiaji. (2009). Raup Rupiah dari Sampah Plastik. Pustaka Bina Swadaya. Jakarta.

Pujotomo, Isworo. 2016. Pemanfaatan Sampah Menjadi Sumber Energi. Jurnal Energi dan Kelistrikan. Vol. 8 (2) : 109-113.

Putra, Hijah P dan Yebi Y. 2010. Studi Pemanfaatan Sampah Plastik Menjadi Produk dan Jasa Kreatif. Jurnal Sains dan Teknologi Lingkungan. Vol 2 (1) : 21-31

Sirait, Mita. (2009). Sulap Sampah Plastik Lunak jadi Jutaan Rupiah. B-Frist. Yogyakarta. 